\title{
From Action Potential-Clamp to "Onion-Peeling" Technique - Recording of lonic Currents Under Physiological Conditions
}

\author{
Ye Chen-Izu리, Leighton T. Izu${ }^{1}$, Peter P. Nanasi² and Tamas Banyasz ${ }^{2}$ \\ 1 University of California Davis \\ 2 University of Debrecen \\ 1USA \\ ${ }^{2}$ Hungary
}

\section{Introduction}

Upon stimulation, excitable cells generate a transient change in the membrane potential called Action Potential (AP). The AP is governed by numerous ionic currents that flow in or out of the cell membrane. The goal of cellular electrophysiology is to understand the role of individual ionic currents and the interplay between currents in determining the profile and the time course of AP. A critically important question of the field is how different ionic currents behave individually and interact collectively during the AP cycle in an excitable cell. To answer this question we need to know the dynamic behavior of ionic currents during AP and how these currents work in concert to determine the cell's membrane potential at every moment.

Ionic currents are studied with voltage-clamp technique. Since the introduction of this method, intensive research has been conducted to characterize the kinetic properties of ionic currents. Various versions of the method were used to determine the charge carrier, voltage gating, ligand gating, activation, inactivation, recovery, etc. of individual ionic currents. One variation of the voltage-clamp is the Action Potential-clamp (AP-clamp) which can record the ionic currents during the AP cycle. In this chapter we will review the principles and variations of the AP-clamp technique and discuss the advantages and limitations of the technique. We will discuss and demonstrate how AP-clamp can help us to understand the ionic mechanisms underlying AP by using the experimental data obtained from cardiac cells where these techniques are extensively used to study the fundamental role of the ionic currents and AP dynamics in governing the cardiac function and heart diseases.

\section{The principles of the AP-clamp technique}

In order to determine the profile of ionic currents during $\mathrm{AP}$, extensive efforts have been made in two different approaches: one is to use mathematical models based on the traditional voltage-clamp data to simulate the current profile during AP; another is to experimentally measure the ionic currents under AP-clamp. 
The modeling approach uses the method pioneered by Hodgkin-Huxley (Hodgkin \& Huxley, 1952) to describe the currents using ordinary differential equations and parameters derived from the voltage-clamp data. The standard voltage-clamp experiments were designed to isolate each individual ionic current, and to investigate its kinetic properties including activation, inactivation, recovery etc. Later, more detailed single channel kinetic state models (Mahajan et al., 2008) and molecular structure models (Silva et al., 2009) were also used to describe some channels. However, standard voltage-clamp experiments often used non-physiological conditions. The ion concentrations in the internal and external solutions were usually different from the physiological ionic milieu in order to isolate a particular current. Rectangular voltage pulses, instead of the AP waveform, were used to characterize the biophysical properties of the channel/transporter. In most cases, the intracellular $\mathrm{Ca}^{2+}$ was buffered with chelants and the currents were measured without the $\mathrm{Ca}^{2+}$ transients. These artificial conditions can bring inaccuracies into the data and cause the resultant models to deviate from the physiological reality, as evidenced by the differences between model simulations and experimental measurements. (Decker et al., 2009; Mahajan et al., 2008)

The experimental approach uses the AP-clamp technique to directly record the current profile during AP. The AP-clamp technique is quite simple in principle, although can be challenging in practice. (The technical aspects are discussed below.) The experimental protocol mainly involves the following steps (Figure-1) with some variations. (1) Record the steady state AP of the cell under current-clamp mode (I=0). (2) Apply this AP waveform as the voltage command onto the same cell under voltage-clamp. After reaching steady state, the net current output, $I_{\text {Ref }}$ should be zero. (3) Isolate the current of interest by using its specific blocker to remove it from the net current output, seen as a compensation current from the amplifier, $I_{\text {Comp. }}$ (4) The current of interest is then obtained as the difference current: $I_{\text {Diff }}=I_{\text {Ref }}-I_{\text {Comp. }}$. What happens behind the scene is that the cell's AP, generated by all the membrane currents working in concert, is recorded under current-clamp with $\mathrm{I}=0$. When this $\mathrm{AP}$ is applied as the command voltage onto the same cell under voltage-clamp, the net current output (seen as $I_{\text {Ref }}$ ) should be zero (Doerr et al., 1989; M.E. Starzak \& R. J. Starzak, 1978), and the amplifier does not need to inject any compensation current to maintain the AP as long as the cell condition remains stable. When a particular current is blocked by its specific inhibitor, then the amplifier has to inject a compensation current (seen as $I_{\text {Comp }}$ ) in place of the blocked current in order to maintain the AP under voltage-clamp. This compensation current is the mirror image (negative) of the particular current that had been blocked. Hence, by subtracting $I_{\text {Comp }}$ from $I_{\text {Ref }}$ we can obtain the current that was originally flowing during the AP prior to the specific inhibitor application.

A fundamental difference between the AP-clamp technique and the conventional voltageclamp technique is in the way of separating the current of interest from the other currents. In conventional voltage-clamp experiments, the current of interest is recorded under conditions that suppress all other currents by using custom-made voltage protocols, simplified ionic solutions, and sometimes blocking other 'contaminating' currents. In contrast, the AP-clamp experiments take an opposite approach to record the 'absence of the current' by blocking the current of interest using its specific inhibitor while allowing all other currents to flow during AP. By subtracting the net current output before and after the blocker application, all other currents (unaltered by the blocker) are cancelled out, and the current of interest is thereby obtained. The major advantage of the AP-clamp technique is 
that it enables us to record the ionic currents under in situ conditions (i.e. during AP, with $\mathrm{Ca}^{2+}$ cycling, in a physiological milieu, and undergoing contraction).

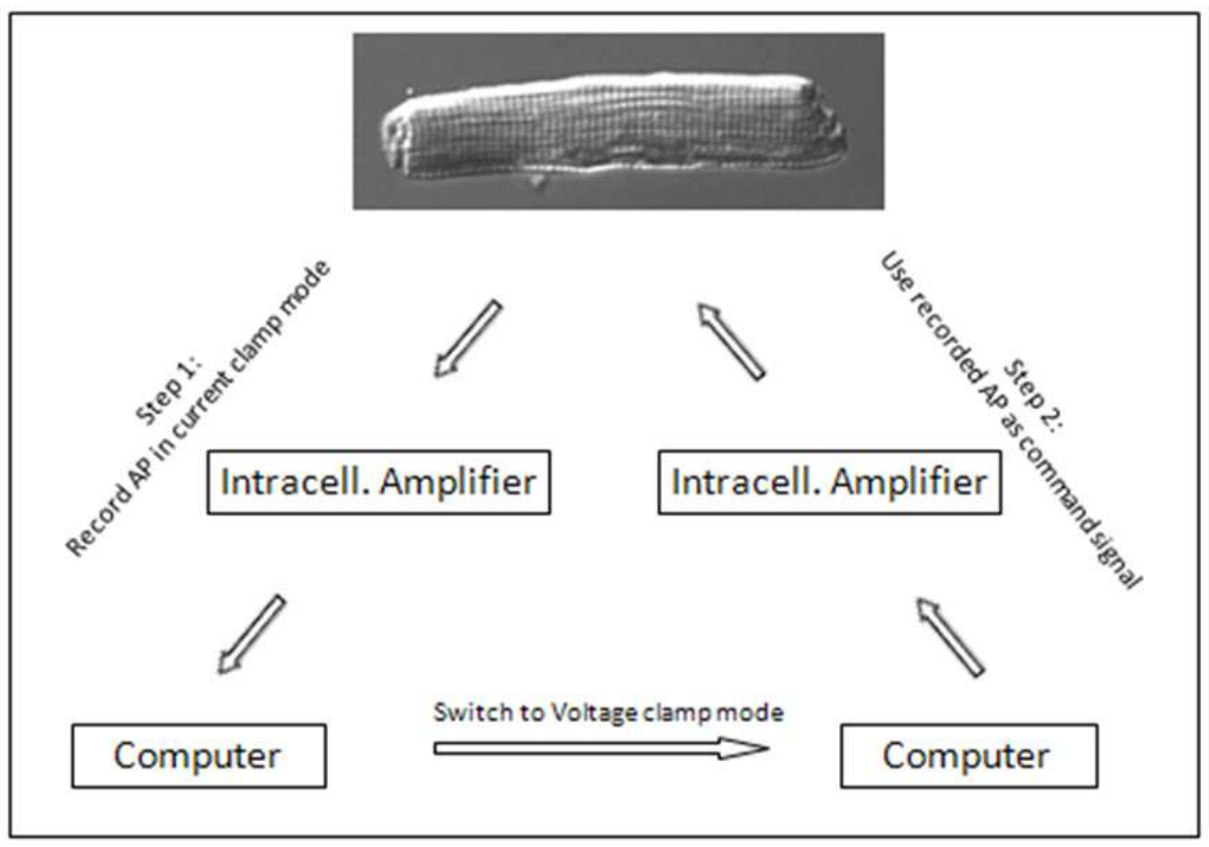

Fig. 1. The Flow chart of the Action Potential-clamp technique.

\section{A short historical review}

Attempts to determine the transmembrane currents during AP-clamp can be dated back to 1970s. One approach used in those pioneering experiments was to switch the amplifier from current-clamp mode to voltage-clamp mode and record the instantaneous current at different phase of AP. The cell was stimulated by a brief current pulse and the action potential was allowed to develop in a free running mode until the amplifier was switched to voltage-clamp mode and the voltage was frozen to the value at that moment for measuring the instantaneous current. (Bezanilla et al., 1970)

At the beginning, the idea to record the membrane current using a pre-recorded AP as the voltage command was used for various applications. Bastian \& Nakajima studied the Ttubule function in skeletal muscle fiber with double sucrose gap method using pre-recorded $\mathrm{AP}$ as the voltage command. (Bastian \& Nakajima, 1974; Nakajima \& Bastian, 1974). In other experiments AP-clamp was used simply to test the effectiveness of the space clamp in axon (M.E. Starzak \& R. J. Starzak, 1978; M.E. Starzak \& Needle, 1983). Though the goals of those early studies were very different from the later studies in which AP-clamp was used to study the contributions of the membrane currents to shaping the AP, we can identify the essential elements of the AP-clamp technique in those experiments. The AP was recorded under current-clamp mode and then stored and used as the command voltage waveform in voltage-clamp mode. Most importantly the concept of 'zero current' is already established in 
those publications: "To produce the most accurate reproduction of this action potential, the voltage clamp currents must include no contributions due to ineffective space clamp" (M.E. Starzak \& R. J. Starzak, 1978).

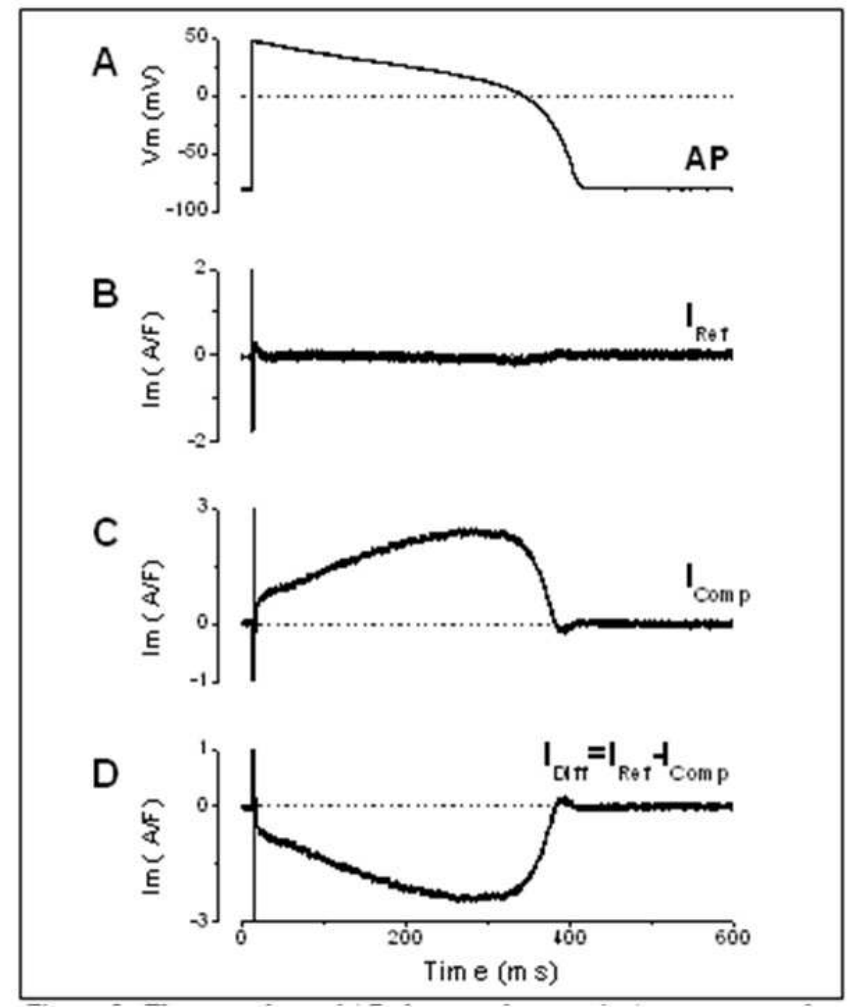

Fig. 2. The procedure of AP-clamp technique. A: Action potential is recorded in current clamp mode. B: Zero current or Reference current $\left(I_{\text {ref }}\right)$ is recorded in voltage clamp mode. C: Using a specific channel inhibitor compensation current $\left(I_{\text {comp }}\right)$ is recorded. D: The inhibitor sensitive current is determined as the difference current

Another technique to measure the membrane conductance during AP (without using prerecorded AP) utilizes two electrodes (Fischmeister et al., 1984; Mazzanti \& DeFelice, 1987). The first electrode had access to the cell's interior for recording the membrane potential under current-clamp mode; the second electrode was sealed to a patch of membrane in cellattached configuration and clamped to the desired voltage (under voltage-clamp mode. The fundamental difference between this technique and the AP-clamp method are twofold. First, the two electrode technique recording of the current is limited only to the membrane patch inside the second pipette; hence only the current of limited number of channels and sometimes only single channel recording were performed. Second, the AP was not controlled with this method; hence variability of the APs would result in variability of the currents and sometimes this method was used to record membrane currents during spontaneous AP (Jackson et al., 1982). 
The breakthrough took place during 1990s following three important publications. Trautwein and his colleagues used digitized AP from spontaneously beating rabbit sinoatrial node cell (Doerr et al., 1989) to stimulate the guinea pig ventricular myocyte (Doerr et al., 1990) and to record membrane currents during AP. In both cases, specific blockers (D-600, $\mathrm{Ni}^{2+}$ ) and current subtraction were used to dissect the ionic currents during AP. These two papers were the first to describe the profile of individual ionic currents (L and T-type calcium currents) directly recorded during AP. By using specific blockers and current subtraction, they established the basic principles of the AP-clamp method. The third paper published AP clamp data obtained in nerve fiber also using the specific blocker and the current subtraction method to visualize sodium and potassium currents during AP (de Haas \& Vogel, 1989). AP-clamp technique became a popular tool during 1990s and was used for mapping the key membrane currents that shape AP in several cell types including cardiac myocytes (Bouchard et al., 1995), neurocytes (Barra, 1996), as well as plant cells (Thiel, 1994). Combined with epifluorescent $\mathrm{Ca}^{2+}$ measurement, AP-clamp technique became a powerful tool for studying the $\mathrm{Ca}^{2+}$ dynamics in cardiac myocytes (Arreola et al., 1991; Grantham \& Cannell, 1996; Puglisi et al., 1999).

During 2000s, a unique variation of the AP-clamp, called Dynamic Clamp technique, was developed in which an isolated cell (or a mathematical model of the cell) is coupled electrically to another cell. The first cell or the model provides the AP that is used as the voltage command onto the second cell (Bereczki et al., 2005; Wilders, 2006). The greatest advantage of the Dynamic Clamp is that the AP obtained from the first cell or model can be manipulated by changing the conditions (ionic milieu, stimulation parameters...etc.) or model parameters. This allows the experimenter to study the effects of changing AP on the dynamics of the currents.

A further extension of AP clamp technique is the sequential dissection of membrane currents or the "Onion-Peeling" (O-P) method. Previously, traditional voltage-clamp and AP-clamp technique was used to record only one current in any one cell. The O-P method uses a series of channel blockers to sequentially dissect out the currents in a single cell under AP-clamp. (Banyasz et al., 2011; Banyasz et al., 2012) The ability to measure many currents in a single cell enables study of the Individual Cell Electrophysiology of excitable cells.

\section{Variations of the AP-clamp technique}

Since the AP-clamp technique was introduced, several variations of the technique have been implemented. These variants use different modifications to circumvent technical limitations and provide new information on the properties of ionic currents. It is not our intension to discuss all possible modifications; here we list the characteristic features of several most frequently used variants.

\subsection{Using 'standardized' or 'typical' AP}

Individual cells display distinctive APs with some degree of cell-to-cell variations. To eliminate the individual variations of AP, a "characteristic or standardized" AP can be used instead of the cell's own AP as the command voltage in AP-clamp (Arreola et al., 1991). This AP could be obtained from a 'typical' cell, tissue or generated by a mathematical model. The 
consequence of using such standardized AP instead of the cell's own AP is that the reference current is no longer flat $\left(I_{R e f} \neq 0\right)$. Development of any kind of deflection from the zero level or appearance of a hump on the reference (zero) current may be an indicator of rundown or some other type of instability. This advantage, i.e. the possibility of monitoring the stability of our preparations is lost when a foreign AP is used as a voltage command. The pharmacological subtraction is also a crucial and necessary step here; the difference current gives the drug-sensitive current.

\subsection{Using 'modified' or 'reconstructed' AP}

Modified or reconstructed AP was used in some AP-clamp experiments for various reasons. Some were designed to tease out certain properties of the currents; some were to circumvent technical difficulties. For example, such a situation is generated when we need to record a delayed potassium current with small amplitude in the range of 0.1-0.5 nA. This current can be recorded with good resolution if the amplifier is set to $\pm 1-2 \mathrm{nA}$ input range. Nevertheless, this setting cannot reliably hold the voltage clamp during the upstroke of the AP where the voltage dependent $\mathrm{Na}^{+}$channels generate a large current with 100-150 nA peak amplitude. We have two equally poor options here. If we keep the amplifier Gain high to maintain the high resolution, the voltage clamp at the beginning of the AP would be lost. If we lower the Gain, the fidelity of the voltage clamp would be kept but the resolution of the current recording would be poor. To prevent loosing the voltage clamp, we can modify the AP by adding a short depolarizing step (i.e. $10 \mathrm{~ms}$, to $-30 \mathrm{mV}$ ) prior to the upstroke of the AP. (Varro et al., 2000) This depolarizing step can inactivate the voltage dependent $\mathrm{Na}^{+}$channels to allow the amplifier to hold the voltage clamp, and thereby circumvent this technical problem. Modification of other parameters of the AP (duration, plateau height, diastolic interval etc.) can also be used in AP-clamp experiments to study the ionic mechanisms that shape the AP. (Rocchetti et al., 2001)

\subsection{Dynamic Clamp}

A special variant of the AP-clamp method is the Dynamic Clamp (Bereczki et al., 2005; Wilders, 2006). In this case the AP voltage command comes from a current-clamped cell (Cell -1) or, alternatively, from a mathematical model. This AP waveform is used as the command voltage to voltage-clamp another cell (Cell-2). The current recorded from the Cell2 is then fed back to the Cell-1 or to the mathematical model so it can modify the morphology of the AP accordingly. In this configuration, the two systems are in dynamic connection and in real time coupling.

Originally developed to study interactions between neural cells, the Dynamic Clamp technique provides a powerful tool for studying the dynamic interaction of currents and AP. For example, Weiss et al (Mahajan et al., 2008) used Dynamic Clamp method to investigate the $\mathrm{Ca}^{2+}$ modulation of ionic currents during AP in the cardiac myocyte. They first eliminated the intracellular $\mathrm{Ca}^{2+}$ cycling (by depleting the SR load), and then used mathematical model ('Cell-1') to generate the $\mathrm{Ca}^{2+}$ transient and feed the data into an APclamped cell (Cell-2) to record the L-type $\mathrm{Ca}^{2+}$ current. The data provide valuable information on how the L-type $\mathrm{Ca}^{2+}$ channel are modulated by the $\mathrm{Ca}^{2+}$ transient during AP cycle. 


\subsection{The "Onion-Peeling" (O-P) technique}

Recently, a new version of the AP-clamp method was developed, called "Onion-Peeling" (O-P) technique, by making two significant modifications (Banyasz et al., 2011; Banyasz et al., 2012): (1) a triad of conditions is used to directly record ionic currents during AP, with $\mathrm{Ca}^{2+}$ cycling, in a physiological milieu; (2) multiple ionic currents are recorded from the same cell by sequentially applying the channel blockers one-by-one to dissect out each of the ionic currents. Figuer- 2 shows the recording of four different currents $\left(I_{\mathrm{Ks}}\right.$ : chromanol, $I_{\mathrm{Kr}}$ : E4031, $I_{\mathrm{K} 1}: \mathrm{Ba}^{2+}$, and $I_{\mathrm{NISO}}$ : nisoldipine sensitive current) in a single guinea pig ventricular myocyte using the O-P technique. All currents are recorded after reaching steady state. To directly record the ionic currents during $\mathrm{AP}$ with $\mathrm{Ca}^{2+}$ cycling in a physiological milieu allows us to construct accurate and realistic models. The unprecedented ability to measure multiple currents in the same cell enables us to study the Individual Cell Electrophysiology (see below).

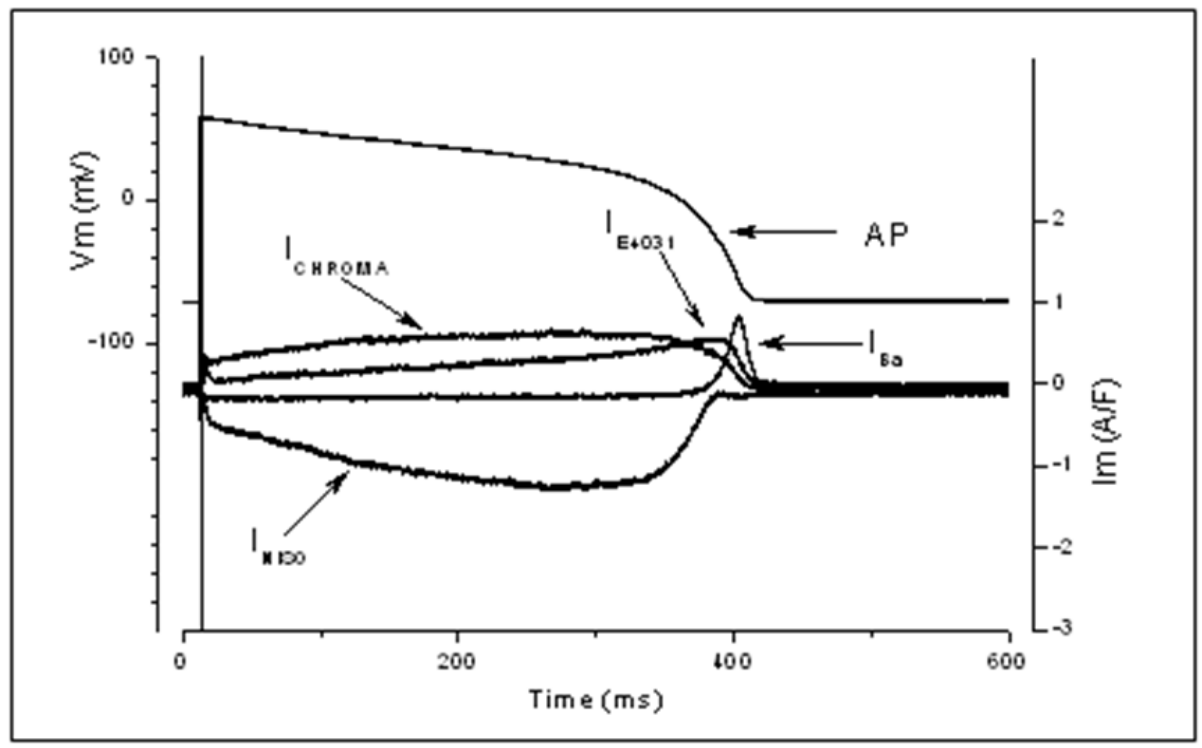

Fig. 3. Onion Peeling recording of multiple currents in guinea pig ventricular myocytate. AP: Action Potential.

$\mathrm{I}_{\mathrm{CHROMA}}, \mathrm{I}_{\mathrm{Ba}}, \mathrm{I}_{\mathrm{NISO}}, \mathrm{I}_{\mathrm{E} 4031}$ detones Chromanol-293B, $\mathrm{Ba}^{2+}$, Nisoldipine and E4031 sensitive currents respectively.

\section{Applications of the AP-clamp and Onion-Peeling (O-P) methods}

\subsection{Study of the Individual Cell Electrophysiology (ICE)}

The cell's AP is a finely choreographed dance involving many ion channels and transporters interacting with each other via the membrane potential and intracellular $\mathrm{Ca}^{2+}$. How do we determine the role of individual ion channel/transporter in shaping the AP and which channels/transporters are altered by disease, stress, drug etc.? Traditional voltage-clamp studies record one current from any one cell, and different currents from different cells. The 
data averaged from many cells are then used to construct a canonical AP model. However, the averaged canonical AP model may not reflect the behavior of single cells due to cell-tocell variability. (Marder \& Taylor, 2011) It has been known that discrepancies exist between the model simulations and the AP-clamp measured current (Banyasz et al., 2011), and model simulations still fail to reproduce some important AP dynamic behaviors (i.e. EAD, adaptation, restitution) ( Decker et al., 2009; Faber et al., 2007; Mahajanaw et al., 2008; Pasek et al., 2008).

The significant contribution of the O-P technique is that it provides a new and different type of data from all previous voltage-clamp experiments; the O-P technique allows recording of multiple ionic currents flowing through different channels/transporters during AP in the same single cell (see Figure 3). The ability to measure multiple ionic currents in the same cell provide experimental data to directly study how inward and outward currents work concertedly to shape the AP in individual cells, and hence the Individual Cell Electrophysiology (ICE).

The cell's AP is shaped by all of the currents flowing across the cell membrane via ion channels, exchangers, transporters etc. In order to gain in-depth quantitative understanding of the ionic mechanisms that control the AP and arrhythmias, we need to study how different currents interact and integrate at the single cell level. Due to cell-to-cell variability in the protein expression and modulation, the density of certain ionic currents may vary in different cells. Nevertheless if the inward and the outward currents can counterbalance one another, different combinations of the currents can generate similar APs. (Banyasz et al., 2011) Under pathological conditions, disproportional changes in some currents may upset the balance to cause long or short AP duration, early or delayed afterdepolarizations that lead to arrhythmias. Using O-P to measure multiple currents in the same cell provides necessary data for determining how the proportion of the currents is altered to upset the balance and cause arrhythmogenic APs. Furthermore, disease conditions may widen the heterogeneity among cells to cause more pronounced cell-to-cell variability. Using O-P to conduct the ICE study will be critically important for understanding the impact of cellular variability (inherent variance, transmural gradient, regional difference, disease associated variance, etc.) on the population behavior at tissue and organ levels.

\subsection{Mapping the regional and transmural differences}

It has long been known that the AP morphology has characteristic epicardial versus endocardial differences: a spike-and-dome AP profile was seen in the epi-, but not in the endocardial ventricular myocytes from canine and human hearts. Early studies show that different $\mathrm{K}^{+}$current density in different layers of the myocardium may contribute to this heterogeneity (Litovsky \& Antzelevitch, 1988; Liu et al., 1993; Liu \& Antzelevitch, 1995). When L-type $\mathrm{Ca}^{2+}$ currents $\left(\mathrm{I}_{\mathrm{Ca}, \mathrm{L}}\right)$ of epi- and endocardial ventricular myocytes were compared using traditional voltage-clamp technique, the voltage dependence, activation and inactivation kinetics of the currents were found to be identical. Interestingly, when the profile of $\mathrm{I}_{\mathrm{Ca}, \mathrm{L}}$ was studied as the nisoldipine-sensitive current using the AP-clamp technique, marked differences were observed between epi- and endocardial cells. Although $\mathrm{I}_{\mathrm{Ca}, \mathrm{L}}$ showed a sharp spike followed by a rapid decay in both endo- and epicardial cells following the upstroke of the AP, a hump developed in the $\mathrm{I}_{\mathrm{Ca}, \mathrm{L}}$ record in the epi- but not in the endocardial cells. (Banyasz et al., 2003) Similar transmural differences were also 
obtained in ventricular myocytes isolated from human hearts (Fulop et al., 2004). This double-peaked morphology of $\mathrm{I}_{\mathrm{Ca}, \mathrm{L}}$ in epi-cardial cells and the relationship between the profile of $\mathrm{AP}$ and $\mathrm{I}_{\mathrm{Ca}, \mathrm{L}}$ was revealed only under AP-clamp but not with traditional voltageclamp method. The AP-clamp technique provides a direct method for studying the relationship between currents and membrane potential during AP.

\subsection{Studying the complex effects of pathological conditions}

Cardiac arrhythmias are a leading cause of morbidity and mortality in the developed world. Yet, pharmacological approaches to treat arrhythmias have met with only limited success, in large part due to incomplete understanding of the cellular and molecular mechanisms of arrhythmias. Pathological conditions wrought by disease, stress, drug etc. usually cause complex changes in multiple ion channels/transporters and $\mathrm{Ca}^{2+}$ handling molecules. The changes in proteins involved in determining electrical currents of the cardiac myocytes can cause abnormalities in the profile and the time course of APs, leading to arrhythmias. To elucidate the pathologic mechanisms behind abnormal APs one needs to understand the changes in the kinetics of ionic currents. For example, in a rabbit model of pressure \& volume overload induced non-ischemic heart failure, researchers have found changes in several key channel/transporter that determine the cardiac AP and arrhythmias (Pogwizd, 1995; Pogwizd et al., 2001): $\mathrm{I}_{\mathrm{K} 1}$, an important $\mathrm{K}^{+}$current that controls the repolarization of $\mathrm{AP}$, was reduced; the $\mathrm{Na}^{+} / \mathrm{Ca}^{2+}$ exchanger, a key regulator of the $\mathrm{Ca}^{2+}$ signaling and $\mathrm{AP}$ profile, was up-regulated; the expression of B-adrenergic receptors, which profoundly influence the $\mathrm{AP}$ and the $\mathrm{Ca}^{2+}$ signaling was also altered. The reduced repolarization power (weakened $\mathrm{I}_{\mathrm{K} 1}$ ) combined with augmented depolarizing drive (up-regulated $\mathrm{Na}^{+} / \mathrm{Ca}^{2+}$ exchanger current), and probably more, changes at molecular level manifest at cellular level to cause delayed afterdepolarizations which can trigger premature APs. The abnormal APs at the cellular level further manifest at the tissue and organ level to cause cardiac arrhythmias. These changes in the rabbit heart failure model resemble some of the changes found in human congestive heart failure (Nattel et al., 2007).

Traditionally, the dynamic behavior of ionic currents during AP was studied using voltage-clamp experiments in conjunction with mathematical modeling. The standard voltage-clamp technique uses custom-made voltage protocols to determine the voltage dependency and the kinetic properties of each individual current. As a basic rule, only one single current can be measured from any one cell because different experimental conditions (ionic milieu, voltage protocol, inhibitors to block contaminating currents etc.) are required to record different current. For example, it is impossible to record $I_{K 1}$ and $\mathrm{Na}^{+} / \mathrm{Ca}^{2+}$ exchanger current from the same cell using standard voltage-clamp technique. The novelty of the O-P technique is that it enables recording of multiple currents from the same single cell, by sequentially applying specific inhibitors of different currents under AP-clamp. The O-P technique gives us unprecedented ability to conduct the ICE study of the complex effects of pathological conditions on altering multiple currents and to study their collective effects on shaping APs in the single cell. The O-P recording of multiple currents enables us to study how the proportions of different currents are altered in diseased myocardium compared to healthy hearts (see the previous chapter on individual cell electrophysiology). 


\subsection{Characterization of drug effects}

The AP-clamp technique can be used economically for studying drugs with multiple actions. As shown previously, each ionic current has its own characteristic profile during $\mathrm{AP}$, called fingerprint. Knowing the fingerprint of each individual current, we can identify the suspected drug-sensitive currents (perhaps several of them) in a single AP-clamp experiment (Szabo et al., 2007; Szabo et al., 2008). Hence, the profile of the drug-sensitive current recorded under AP-clamp can give clues towards the identity of currents that might be affected by the drug. This initial screening with AP-clamp prior to the systematic pharmacological study can save significant time and resource in studying the drug effects.

Effects of receptor agonists or antagonists (hormones, receptor modulators or drugs) can also be readily studied by AP-clamp. Even in the case when agonist/antagonist affects only one population of receptors, signal transduction pathways often couple to more than one ionic current; AP-clamp is uniquely suited for studying the drug concentration-dependent effects on multiple currents. As example, the frequency-dependent effects of isoproterenol on $\mathrm{I}_{\mathrm{Ca}, \mathrm{L}}, \mathrm{I}_{\mathrm{Ks}}$, and $\mathrm{I}_{\mathrm{Cl}}$ in guinea pig ventricular cells (Rocchetti et al., 2006) and the effects of acetylcholine and adenosine on $\mathrm{I}_{\mathrm{K} 1}$ in ferret cardiac myocytes (Dobrzynski et al., 2002) were clarified using the AP-clamp technique.

\section{Technical aspects}

To successfully perform AP-clamp experiments requires high quality cells and instrumentation. In this chapter we will review the essential technical requirements for the AP-clamp technique.

\subsection{Cell quality and the solutions}

Robust cells with physiological resting membrane potential and stable APs are necessary requirements for using the AP-clamp technique. The experiments are performed in isolated single cells. Preparation of the cells is basically the same as in other voltage-clamp experiments. The only difference is that the composition of the bath solution should mimic the physiologic extracellular milieu during experiments. If the cell preparation requires using non-physiological media, try to minimize the time the cells spend in that media. The $\mathrm{pH}$ and the osmolarity of the solutions must be tightly controlled, and membrane permeable buffers (bicarbonate) seem to improve robustness of the cells. We found that the cells worked better if stored for 1-2 hours in the same extracellular medium as used in the APclamp experiments. Continuous perfusion of the bath solution is needed to maintain the cell quality throughout the experiments.

To work with a contracting muscle cell, the whole-cell seal usually last longer if we lift the cell up from the bottom of perfusion chamber after establishing the seal (no need to do this for other non-contracting cell types). However, sometimes cells tend to stick to the bottom of the perfusion chamber. Adding a small drop of the albumen solution into the chamber before the cells are placed can reduce the stickiness of the cells without reducing the success rate for seal formation.

The pipette solution used for the AP-clamp experiment should mimic the intracellular ionic milieu of the cell. Again, tight control of the $\mathrm{pH}$ and the osmolarity of the solutions 
are crucial. Traditionally, 2-10 mmol/L EGTA is added to the pipette solution in voltageclamp experiments to buffer cytosolic $\mathrm{Ca}^{2+}$ and eliminate cell contraction when working with muscle cells. Buffering the cytosolic $\mathrm{Ca}^{2+}$ can lengthen the lifetime of the seal significantly, and the previous voltage-clamp and AP-clamp experiments used $\mathrm{Ca}^{2+}$ buffers in most cases. However, our recent studies using the O-P technique (Banyasz et al., 2012) demonstrate that the current profiles during AP with $\mathrm{Ca}^{2+}$ transient $\left(\mathrm{Ca}^{2+}\right.$ cycling preserved by not using exogenous $\mathrm{Ca}^{2+}$ buffer in the pipette solution) can be significantly different from the currents recorded with buffered $\mathrm{Ca}^{2+}$ (2-10 mM EGTA or BAPTA were used). Therefore, in order to record the ionic currents under physiological condition in situ, we suggest to minimize the use of exogenous $\mathrm{Ca}^{2+}$ buffer in the pipette solution and to measure the $\mathrm{Ca}^{2+}$ transient simultaneously with the O-P recording of the currents during AP.

Before recording the steady state AP to use as the voltage command for AP-clamp, we need to first test stability of the AP parameters. Keep in mind that the AP duration is never strictly constant, as a living system usually has some fluctuation in parameters. If the beat-to-beat fluctuation in the APs is large, the cell cannot be used for the AP-clamp experiment. We usually use the cells with no more than $4-5 \%$ fluctuation in the AP duration. At the same time, we use very stringent requirements for the voltage parameters. The cell must be discarded if any of the voltage parameters (resting membrane potential, peak amplitude, plateau height... etc.) displays more than $1 \mathrm{mV}$ instability. Depending on the input impedance of the cell, $\leq 1 \mathrm{mV}$ of instability in the voltage could translate into several hundred $\mathrm{pA}$ of fluctuation in the current measurements. We found it useful to stimulate the cell for 15-20 minutes at a constant pacing rate until it truly reaches a steady state, and then record the AP under currentclamp mode. Also, depending on the geometry of the cell it might take 15-20 minutes of pacing for the cell to reach equilibrium between the cytoplasm and the pipette solution after establishing the whole-cell ruptured seal configuration.

\subsection{The patch pipette and the whole-cell seal configuration}

The requirements for patch pipette used for the AP-clamp technique are the same as for those used in traditional voltage-clamp experiments. We use borosilicate glass pipette with tip resistance of 1.5-2.5 M . The technical details of pipette fabrication follow the direction from the pipette puller manufacturer.

After compensating for the junction potential between the pipette solution and the bath solution, the pipette tip is placed on the cell membrane and a gentle suction is used to make a G $\Omega$ seal. Then the membrane patch inside the pipette is ruptured by suction to establish the whole-cell seal configuration. As a critical requirement for the AP-clamp technique, the access resistance must be kept low $(<5 \mathrm{M} \Omega)$ and constant throughout the entire experiment, because a change in the access resistance exerts significant impact on the magnitude and the dynamics of the compensation current. We suggest recording the access resistance at the beginning and at the end of the AP-clamp experiment and checking it several times during the experiment. It is important that the access resistance should remain close to the initial value throughout; if it changes significantly, the cell should be discarded from data collection. 
The cell capacitance cancellation and the series resistance compensation are necessary for speeding up the capacitive transient and maintaining high fidelity of the actual voltage command across the cell membrane. When both are engaged, it is somewhat difficult to adjust the degrees of compensation without provoking 'ringing' (oscillations in the compensation circuitry), especially when dealing with large size cardiac myocytes (150-300 $\mathrm{pF}$ ). Hence it is practically impossible to achieve $100 \%$ compensation. In our experience, about $80 \%$ compensation with $20 \mu \mathrm{s}$ Lag is feasible for a typical cardiac myocyte without risking the 'ringing'. Higher percentage of compensation should be achievable for other cell types with smaller whole cell capacitance.

After breaking the membrane patch to establish the whole-cell seal, a junction potential would build up between the pipette solution and the cytosol. The magnitude of this junction potential can be as high as $10-15 \mathrm{mV}$ depending on the composition of the pipette solution, and seen as an apparent depolarization of the membrane. It is essential not to compensate this junction potential to avoid imposing a voltage shift into the measurement. It can be somewhat deceptive when the reading of the resting membrane potential appears 10-15 $\mathrm{mV}$ higher than the known physiologic value and the temptation might be very strong to eliminate this apparent voltage shift. But doing so would destroy the AP-clamp measurements. In the design of the AP-clamp technique, this junction potential is automatically taken care of (dropped out from the equation) during the current subtraction. Nevertheless, if we want to analyze the voltage dependence of the currents, this junction potential must be corrected in the voltage values and taken into consideration during the analysis.

\subsection{Instrumentation}

The instruments (amplifier, A/D converter, computer etc.) used in AP-clamp experiments are basically the same as for voltage-clamp experiments. The specifications are determined by the cell type and current parameters we want to measure. However, there are some special considerations in deciding what particular instruments to use for the AP-clamp experiment.

- External stimulator: it is very useful (albeit not essential) to have an external stimulator to generate the electric pulses for evoking the AP. Although most electrophysiology software offers the option to program square pulse protocol to stimulate the cell in current-clamp mode, modification/adjustment of stimulation parameters (changing the amplitude or pacing rate) is more complicated and time consuming (if we have to overwrite protocol parameters) than simply turning the control knobs on the stimulator (analogue stimulator, for example). If we decide to use a square pulse generator to stimulate the cell it must be a DC stabile device, and the zero level should be truly zero with extremely low noise. Note that the manufacturer specification usually uses the maximum output voltage as reference to calculate the noise level, but we use no more than 5-10 V voltage range for the AP-clamp experiment, so the noise of the instrument needs to be extremely low.

- Amplifier: If we decide to use an external stimulator, the amplifier should have at least one command potential input compatible with the stimulator. It is also necessary to calibrate the amplifier frequently, because the AP-clamp experiment is more sensitive to voltage drift than traditional voltage-clamp experiments. 


\subsection{Channel inhibitors}

The quality of AP-clamp data is determined primarily by the selectivity of the channel blocker used in pharmacological dissection of the current. In ideal situation, we have a highly specific drug which can selectively block the current under study without affecting any other currents. In such cases, using maximal concentration of the drug is suggested. Unfortunately, some drugs are known to have side effects on other channels besides their primary target. Using these non-specific drugs in the AP-clamp experiment would yield a composite current contaminated with other current(s).

\begin{tabular}{|c|c|c|c|}
\hline $\begin{array}{c}\text { Ion Channel \& } \\
\text { Transporter }\end{array}$ & Inhibitor & Dosage & Reference \\
\hline $\mathbf{I}_{\mathrm{Na}}$ & TTX & $1-10 \mu \mathrm{m}$ & $\begin{array}{l}\text { Chorvatova et al 2004; Yuill } \\
\text { et al } 2000\end{array}$ \\
\hline $\mathbf{I}_{\text {Na-Late }}$ & Ranolazine & $10 \mu \mathrm{m}$ & Rajamani et al 2009 \\
\hline $\mathrm{I}_{\mathrm{Ca}-\mathrm{L}}$ & Nifedipine & $1 \mu \mathrm{m}$ & Horiba et al 2008 \\
\hline $\mathbf{I}_{\mathrm{Ca}-\mathrm{L}}$ & Nisoldipine & $0.1 \mu \mathrm{m}$ & Banyasz et al 2003 \\
\hline $\mathbf{I}_{\mathrm{NCX}}$ & SEA0400 & $3 \mu \mathrm{m}$ & $\begin{array}{l}\text { Birinyi et al 2005; Ozdemir et } \\
\text { al } 2008\end{array}$ \\
\hline $\mathbf{I}_{\mathrm{Cl}-\mathrm{Ca}}$ & $\begin{array}{l}\mathrm{N}-(\mathrm{p}- \\
\text { amylcinnamoyl) } \\
\text { anthranilic acid }\end{array}$ & $5 \mu \mathrm{m}$ & Gwanyanya et al 2010 \\
\hline $\mathbf{I}_{\text {to }}$ & 4-aminopyridine & $1 \mathrm{mM}$ & $\begin{array}{l}\text { Banyasz et al 2007; Patel \& } \\
\text { Campbell } 2005\end{array}$ \\
\hline $\mathbf{I}_{\mathrm{kr}}$ & $\mathrm{E} 4031$ & $1 \mu \mathrm{M}$ & $\begin{array}{l}\text { Banyasz et al 2007; Varro et } \\
\text { al } 2000\end{array}$ \\
\hline $\mathbf{I}_{\mathrm{ks}}$ & HMR-1556 & $30 \mathrm{nM}$ & $\begin{array}{l}\text { Gogelein et al 2000; Thomas } \\
\text { et al } 2003\end{array}$ \\
\hline $\mathbf{I}_{\mathrm{ks}}$ & Chromanol-293B & $1-10 \mu \mathrm{M}$ & Yamada et al 2008 \\
\hline $\mathbf{I}_{\mathbf{k} 1}$ & $\mathrm{BaCl}_{2}$ & $50 \mu \mathrm{M}$ & $\begin{array}{l}\text { Banyasz et al 2008; Banyasz } \\
\text { et al } 2007\end{array}$ \\
\hline $\mathrm{I}_{\mathrm{K}-\mathrm{Ca}}$ & Apmin & $100 \mathrm{pM}, 1 \mathrm{nM}$ & $\begin{array}{l}\text { Xu et al 2003; Özgen et al } \\
2007\end{array}$ \\
\hline $\mathrm{I}_{\mathrm{Cl}-\mathrm{Ca}}$ & Niflumic acid & $50 \mu \mathrm{M}$ & $\begin{array}{l}\text { Greenwood \& Leblanc 2007; } \\
\text { Saleh et al } 2007\end{array}$ \\
\hline $\mathbf{I}_{\mathrm{Cl} \text {-small }}$ & Chlorotoxin & & Borg et al 2007 \\
\hline $\mathbf{I}_{\mathrm{Cl}-\mathrm{vol}}$ & Tamoxifen & & Borg et al 2007 \\
\hline $\mathbf{I}_{\mathrm{Cl}, \text { ligand }}$ & Picrotoxin & & Etter et al 1999 \\
\hline $\mathbf{I}_{\mathrm{Ca}-\mathrm{T}}$ & NNC 55-0396 & & Huang 2004 \\
\hline $\mathbf{I}_{\mathrm{Ca}-\mathrm{T}}$ & $\mathrm{R}(-)$ efodipine & & Tanaka 2004 \\
\hline
\end{tabular}

Table 1. Specific inhibitors for the major ionic currents in cardiac cells. 
How to make sure the O-P current dissected out by the specific channel blocker is pure?

First and foremost, we should use the most specific channel blocker known in literature. Several things can be done to check the specificity of drugs. (A) We do drug dose-response to check that the profile of current scales proportionally. (B) We use low dosage to dissect out a proportion of the target current and minimize non-specific effects. The full magnitude of the current can be recovered using the drug dose-response curve determined by using the traditional voltage-clamp experiments where other (contaminating) currents are eliminated. (C) We scramble the sequence of drug application to make sure there is no crosstalk (Banyasz et al., 2011). If the drug is found to have non-specific effects even at very low dosage, we will search for a more specific blocker (i.e. experimental drugs, venoms, toxins, peptide inhibitors, antibody-targeted inhibitors, etc.) The drug list in Table- 1 is our first pass, but can and will be modified as more specific drugs become available.

Special consideration is needed for recording $\mathrm{Ca}^{2+}$-sensitive currents using the O-P technique. As a charge carrier, $\mathrm{Ca}^{2+}$ current influences the membrane potential. As a ubiquitous second messenger, $\mathrm{Ca}^{2+}$ also influences a number of $\mathrm{Ca}^{2+}$-sensitive currents. The intracellular $\mathrm{Ca}^{2+}$ concentration is kept very low $(100 \mathrm{nM})$ in cells at resting state (diastole in cardiac myocytes). Upon excitation, the $\mathrm{Ca}^{2+}$ inflow during AP drastically elevate the intracellular $\mathrm{Ca}^{2+}$ concentration which triggers many biochemical events and modulate numerous $\mathrm{Ca}^{2+}$-sensitive currents. For example, to record the L-type $\mathrm{Ca}^{2+}$ current using the O-P technique, we use nifedipine to block the L-type $\mathrm{Ca}^{2+}$ channel. However, blocking the L-type $\mathrm{Ca}^{2+}$ current during AP also abolishes the $\mathrm{Ca}^{2+}$ transient, which, in turn, affects other $\mathrm{Ca}^{2+}$-sensitive currents. Thus the nifedipine-sensitive current recorded using O-P technique would consist not only the L-type $\mathrm{Ca}^{2+}$ current but also other $\mathrm{Ca}^{2+}$-sensitive currents including the $\mathrm{Na}^{+} / \mathrm{Ca}^{2+}$ exchanger, $\mathrm{Ca}^{2+}$-activated $\mathrm{K}^{+}$ currents, $\mathrm{Ca}^{2+}$-sensitive $\mathrm{Cl}^{-}$currents and so on. One way to avoid this problem is to first record $\mathrm{Ca}^{2+}$-sensitive currents while $\mathrm{Ca}^{2+}$ is normally cycling, and subsequently to add nifedipine to block the L-type $\mathrm{Ca}^{2+}$ current.

\section{Conclusion}

The AP-clamp methods provide powerful tools for studying the ionic currents under physiological conditions, and the complex effects of disease, stress, drug, mutation etc. on the ion channels and transporters. The O-P technique is uniquely suited for studying the Individual Cell Electrophysiology which is necessary for investigating the cell-to-cell variability. The AP-clamp and the O-P techniques can be used in muscle cells, neural cells, and any excitable cells where ionic currents and membrane potential play important roles in cell function.

\section{References}

Arreola, J.; Dirksen, R.T.; Shieh, R.C.; Williford, D.J. \& Sheu, SS. (1991). Ca2+ current and $\mathrm{Ca}^{2+}$ transients under action potential clamp in guinea pig ventricular myocytes. American Journal of Physiology, Vol.261, pp. C393-C397, ISSN: 00029513 
Banyasz, T.; Fulop, L.; Magyar, J.; Szentandrassy, N.; Varro, A. \& Nanasi PP. (2003). Endocardial versus epicardial differences in L-type calcium current in canine ventricular myocytes studied by action potential voltage clamp. Cardiovascular Research, Vol.58, pp. 66-75, ISSN 00086363

Banyasz, T.; Magyar, J.; Szentandrassy, N.; Horvath, B.; Birinyi, P.; Szentmiklosi, J. \& Nanasi, PP. (2007). Action potential clamp fingerprints of $\mathrm{K}^{+}$currents in canine cardiomyocytes: their role in ventricular repolarization. Acta Physiologica (Oxford), Vol.190, pp. 189-198, ISSN 17481708

Banyasz, T.; Lozinskiy, I.; Payne, C.E.; Edelmann, S.; Norton, B.; Chen, B.; Chen-Izu, Y.; Izu, L.T. \& Balke, C.W. (2008). Transformation of adult rat cardiac myocytes in primary culture. Experimental Physiology, Vol.93, pp. 370-382, ISSN 09580670

Banyasz, T.; Horvath, B.; Jiang, Z.; Izu, L.T. \& Chen-Izu, Y. (2011). Sequential dissection of multiple ionic currents in single cardiac myocytes under action potentialclamp. Journal of Molecular and Cellular Cardiology, Vol.50, pp. 578-581, ISSN 00222828

Banyasz, T.; Horvath, B.; Jiang, Z.; Izu, L.T. \& Chen-Izu, Y. (2012). Profile of L-type Ca2+ current and $\mathrm{Na}^{+} / \mathrm{Ca}^{2+}$ exchange current during cardiac action potential in ventricular myocytes. Heart Rhythm, Accepted for publication, ISSN 15475271

Barra, P.F.A. (1996). Ionic currents during the action potential in the molluscan neurone with the self-clamp technique. Comparative Biochemistry and Physiology Part A: Physiology, Vol.113, pp. 185-194, ISSN 03009629

Bastian, J. \& Nakajima, S. (1974). Action Potential in the Transverse Tubules and Its Role in the Activation of Skeletal Muscle. The Journal of General Physiology, Vol.63, pp. 257278, ISSN 15407748

Bereczki, G.; Zegers, J.G.; Verkerk, A.O.; Bhuiyan, Z.A.; de Jonge, B.; Veldkamp, M.W.; Wilders, R. \& van Ginneken A.C.G. (2005). HERG Channel (Dys)function Revealed by Dynamic Action Potential Clamp Technique. Biophysical Journal, Vol.88, pp. 566578, ISSN 00063495

Bezanilla, F.; Rojas E. \& Taylor, RE. (1970). Sodium and potassium conductance changes during a membrane action potential. Journal of Physiology, Vol.211, pp. 729-751, ISSN 00223751

Birinyi, P.; Acsai, K.; Banyasz, T.; Toth, A.; Horvath, B.; Virag, L.; Szentandrassy, N.; Magyar, J.; Varro, A.; Fulop, F. \& Nanasi PP. (2005). Effects of SEA0400 and KB$\mathrm{R} 7943$ on $\mathrm{Na}^{+} / \mathrm{Ca}^{2+}$ exchange current and L-type $\mathrm{Ca}^{2+}$ current in canine ventricular cardiomyocytes. Naunyn Schmiedebergs Archives of Pharmacology, Vol.372, pp. 63-70, ISSN 00281298

Borg, J.J.; Hancox, J.C.; Zhang, H.; Spencer, C.I.; Li, H. \& Kozlowski, R.Z. (2007). Differential pharmacology of the cardiac anionic background current $\mathrm{I}(\mathrm{AB})$. European Journal of Pharmacology, Vol.569, pp. 163-170, ISSN 00142999

Bouchard, R.A.; Clark, R.B. \& Giles, W.R. (1995). Effects of Action Potential Duration on Excitation-Contraction Coupling in Rat Ventricular Myocytes Action Potential Voltage-Clamp Measurements. Circulation Research, Vol.76, pp. 790-801, ISSN 00097330 
Chorvatova, A.; Snowdon, R.; Hart, G. \& Hussain, M. (2004). Effects of pressure overloadinduced hypertrophy on TTX-sensitive inward currents in guinea pig left ventricle. Molecular and Cellular Biochemistry, Vol.261, pp. 217-226, ISSN 03008177

Decker, K.F.; Heijman, J.; Silva, J.R.; Hund, T.J. \& Rudy, Y. (2009). Properties and ionic mechanisms of action potential adaptation, restitution, and accommodation in canine epicardium. Am J Physiol Heart Circ Physiol., Vol.296, pp. H1017-26, ISSN 03636135

Dobrzynski, H.; Janvier, N.C.; Leach, R.; Findlay, J.B.C. \& Boyett, M.R. (2002). Effects of ACh and adenosine mediated by Kir3.1 and Kir3.4 on ferret ventricular cells. American Journal of Physiology - Heart and Circulatory Physiology, Vol.283, pp. H615-H630, ISSN 00029513

Doerr, Th.; Denger, R. \& Trautwein W. (1989). Calcium currents in single SA nodal cells of the rabbit heart studied with action potential clamp. Pflügers Archiv European Journal of Physiology, Vol.413, pp. 599-603, ISSN 00316768

Doerr, Th.; Denger, R.; Doerr, A. \& Trautwein W. (1990). Ionic currents contributing to the action potential in single ventricular myocytes of the guinea pig studied with action potential clamp. . Pflügers Archiv European Journal of Physiology, Vol.416, pp. 230-237, ISSN 00316768

Etter, A.; Cully, D.F.; Liu, K.K.; Reiss, B.; Vassilatis, D.K.; Schaeffer, J.M. \& Arena JP. (1999). Picrotoxin blockade of invertebrate glutamate-gated chloride channels: subunit dependence and evidence for binding within the pore. Journal of Neurochemistry, Vol.72, pp. 318-326, ISSN 00223042

Faber, G.M.; Silva, J.; Livshitz, L. \& Rudy Y. (2007). Kinetic properties of the cardiac L-type $\mathrm{Ca} 2+$ channel and its role in myocyte electrophysiology: a theoretical investigation. Biophys. J., Vol.92, pp. 1522-43, ISSN 15420086

Fischmeister, R.; DeFelice, L.J.; Ayer, R.K.; Jr., Levi, R. \& DeHaan, R.L. (1984). Channel Currents During Spontaneous Action Potentials in Embryonic Chick Heart Cells The Action Potential Patch Clamp. Biophysical Journal, Vol.46, pp. 267-272, ISSN 00063495

Fulop, L.; Banyasz, T.; Magyar, J.; Szentandrassy, N.; Varro A \& Nanasi P.P. (2004). Reopening of L-type calcium channels in human ventricular myocytes during applied epicardial action potentials Acta Physiologica Scandinavica, Vol.180, pp. 3947, ISSN 00016772

Gogelein, H.; Bruggemann, A.; Gerlach, U.; Brendel, J. \& Busch, A.E. (2000). Inhibition of IKs channels by HMR 1556. Naunyn Schmiedebergs Archives of Pharmacology, Vol.362, pp. 480-488, ISSN 00281298

Grantham, C.J. \& Cannell, M.B. (1996). Ca ${ }^{2+}$ Influx During the Cardiac Action Potential in Guinea Pig Ventricular Myocytes. Circulation Research, Vol.79, pp. 194-200, ISSN 00097330

Greenwood, I.A. \& Leblanc, N. (2007). Overlapping pharmacology of $\mathrm{Ca}^{2+}$-activated $\mathrm{Cl}^{-}$and $\mathrm{K}^{+}$channels. Trends in Pharmacological Sciences, Vol.28, pp. 1-5, ISSN 01656147

Gwanyanya, A.; Macianskiene, R.; Bito, V.; Sipido, K.R.; Vereecke, J. \& Mubagwa, K. (2010). Inhibition of the calcium-activated chloride current in cardiac ventricular myocytes 
by N-(p-amylcinnamoyl)anthranilic acid (ACA). Biochemical and Biophysical Research Communications, Vol.402, pp. 531-536, ISSN 0006291X

de Haas, V. \& Vogel, W. (1989). Sodium and Potassium Currents Recorded During an Action Potential. European Biophysics Journal, Vol.17, pp. 49-51, ISSN 01757571

Hodgkin, A. L. \& Huxley, A. F. (1952). A quantitative description of membrane current and its application to conduction and excitation in nerve. Journal of Physiology, Vol.117, pp. 500-544. ISSN 00223751

Horiba, M.; Muto, T.; Ueda, N.; Opthof, T.; Miwa, K.; Hojo, M.; Lee, J.K.; Kamiya, K.; Kodama, I. \& Yasui, K. (2008). T-type $\mathrm{Ca}^{2+}$ channel blockers prevent cardiac cell hypertrophy through an inhibition of calcineurin-NFAT3 activation as well as Ltype $\mathrm{Ca}^{2+}$ channel blockers. Life Sciences, Vol.82, pp. 554-560, ISSN 00243205

Huang, L.; Keyser, B.M.; Tagmose, T.M.; Hansen, J.B.; Taylor, J.T.; Zhuang, H.; Zhang, M.; Ragsdale, D.S. \& Li M. (2004). NNC 55-0396 [(1S,2S)-2-(2-(N-[(3-benzimidazol-2yl)propyl]-N-methylamino)ethyl)-6-fluo ro-1,2,3,4-tetrahydro-1-isopropyl-2naphtyl cyclopropanecarboxylate dihydrochloride]: a new selective inhibitor of Ttype calcium channels. Journal of Pharmacology and Experimental Therapeutics, Vol.309, pp. 193-199, ISSN: 00223565

Jackson, M.B.; Lecar, H.; Brenneman, D.E.; Fitzgerald, S. \& Nelson P.G. (1982). Electrical Development in Spinal Cord Cell Culture. The Journal of Neuroscience, Vol.2, pp. 1052-1061, ISSN 15292401

Litovsky, S.H. \& Antzelevitch, C. (1988). Transient outward current prominent in canine ventricular epicardium but not endocardium. Circulation Research, Vol.62, pp. 116126, ISSN 00097330

Liu, D.W.; Gintant, G.A. \& Antzelevitch, C. (1993). Ionic bases for electrophysiological distinctions among epicardial, midmyocardial, and endocardial myocytes from the free wall of the canine left ventricle. Circulation Research, Vol.72, pp. 671-687, ISSN 00097330

Liu, D.W. \& Antzelevitch, C. (1995). Characteristics of the delayed rectifier current $\left(\mathrm{I}_{\mathrm{Kr}}\right.$ and $\mathrm{I}_{\mathrm{KS}}$ ) in canine ventricular epicardial, midmyocardial and endocardial myocytes. A weaker $\mathrm{I}_{\mathrm{Ks}}$ contributes to the longer action potential of the $\mathrm{M}$ cell. Circulation Research, Vol.76, pp. 351-365, ISSN 00097330

Mahajan, A.; Shiferaw, Y.; Sato, D.; Baher, A.; Olcese, R.; Xie, L-H.; Yang, M.; Chen, P-S.; Restrepo, J. G.; Karma, A.; Garfinkel, A.; Qu, Z. \& Weiss, J. N. (2008). A rabbit ventricular action potential model replicating cardiac dynamics at rapid heart rates. Biophys. J., Vol.94, pp. 392-410, ISSN 00063495

Marder, E. \& Taylor, A. L. (2011). Multiple models to capture the variability in biological neurons and networks. Nat. Neurosci. Vol.14, pp. 133-138, ISSN 1097-6256

Mazzanti, M. \& DeFelice L.J. (1987). Na Channel Kinetics During the Spontaneous Heart Beat in Embryonic Chick Ventricular Cells. Biophysical Journal, Vol.52, pp. 95-100, ISSN 00063495

Nakajima, S. \& Bastian, J (1974). Double Sucrose-Gap Method Applied to Single Muscle Fiber of Xenopus laevis. The Journal of General Physiology, Vol.63, pp. 235-256, ISSN 15407748 
Nattel, S.; Maguy, A.; Le Bouter, S. \& Yeh, Y-H. (2007). Arrhythmogenic Ion-Channel Remodeling in the Heart: Heart Failure, Myocardial Infarction, and Atrial Fibrillation. Physiological Reviews, Vol.87, pp. 425-456, ISSN 00319333

Ozdemir, S.; Bito, V.; Holemans, P.; Vinet, L.; Mercadier, J.J.; Varro, A. \& Sipido, K.R. (2008) Pharmacological inhibition of na/ca exchange results in increased cellular $\mathrm{Ca}^{2+}$ load attributable to the predominance of forward mode block. Circulation Research, Vol.102, pp. 1398-1405, ISSN 00097330

Özgen, N.; Dun, W.; Sosunov, E.A.; Anyukhovsky, E.P.; Hirose, M.; Duffy, H.S.; Boyden, P.A. \& Rosen, M.R. (2007). Early electrical remodeling in rabbit pulmonary vein results from trafficking of intracellular SK2 channels to membrane sites. Cardiovascular Research, Vol.75, pp. 758-769, ISSN 00086363

Pasek, M.; Simurda, J.; Orchard, C.H. \& Christe, G. (2008). A model of the guinea-pig ventricular cardiac myocyte incorporating a transverse-axial tubular system. Progress in Biophysics and Molecular Biology, Vol.96, pp. 258-80, ISSN 00796107

Patel, S.P. \& Campbell, D.L. (2005). Transient outward potassium current, 'Ito', phenotypes in the mammalian left ventricle: underlying molecular, cellular and biophysical mechanisms. Journal of Physiology, Vol.569, pp. 7-39, ISSN 00223751

Pogwizd, S. M. (1995). Nonreentrant Mechanisms Underlying Spontaneous Ventricular Arrhythmias in a Model of Nonischemic Heart Failure in Rabbits. Circulation Vol.92, pp. 1034-1048, ISSN 00097322

Pogwizd, S.M.; Schlotthauer, K.; Li, L.; Yuan, W. \& Bers, D.M. (2001). Arrhythmogenesis and Contractile Dysfunction in Heart Failure : Roles of Sodium-Calcium Exchange, Inward Rectifier Potassium Current, and Residual beta-Adrenergic Responsiveness. Circulation Research Vol.88, pp. 1159-1167, ISSN 00097330

Puglisi, J.L.; Yuan, W.; Bassani, W.M \& Bers, D.M. (1999). $\mathrm{Ca}^{2+}$ Influx Through $\mathrm{Ca}^{2+}$ Channels in Rabbit Ventricular Myocytes During Action Potential Clamp: Influence of Temperature. Circulation Research, Vol.85, pp. e7-e16, ISSN 00097330

Rajamani, S.; El-Bizri, N.; Shryock, J.C.; Makielski, J.C. \& Belardinelli, L. (2009). Usedependent block of cardiac late $\mathrm{Na}^{+}$current by ranolazine. Heart Rhythm, Vol.6, pp. 1625-1631, ISSN 15475271

Rocchetti, M.; Besana, A.; Gurrola, G.B.; Possani, L.D. \& Zaza A. (2001). Rate dependency of delayed rectifier currents during the guinea-pig ventricular action potential. Journal of Physiology, Vol.534, pp. 721-732, ISSN 00223751

Rocchetti, M.; Freli, V.; Perego, V.; Altomare, C.; Mostacciuolo, G. \& Zaza, A. (2006). Rate dependency of $\beta$-adrenergic modulation of repolarizing currents in the guinea-pig ventricle. Journal of Physiology, Vol.574, pp. 183-193, ISSN 00223751

Saleh, S.N.; Angermann, J.E.; Sones, W.R.; Leblanc, N.; Greenwood I.A. (2007). Stimulation of $\mathrm{Ca}^{2+}$-gated $\mathrm{Cl}^{-}$currents by the calcium-dependent $\mathrm{K}^{+}$channel modulators NS1619 [1,3-dihydro-1-[2-hydroxy-5-(trifluoromethyl)phenyl]-5(trifluoromethyl)-2 H-benzimidazol-2-one] and isopimaric acid. Journal of Pharmacology and Experimental Therapeutics, Vol.321, pp. 1075-1084, ISSN: 00223565 
Starzak, M. E. \& Starzak R. J. (1978). An Action Potential Clamp to Probe the Effectiveness of Space Clamp in Axons. IEEE Transactions On Biomedical Engineering, Vol.BME-25, pp. 201-204, ISSN 00189294

Starzak, M. E. \& Needle M. (1983). The Action Potential Clamp as a Test of Space-Clamp Effectiveness - The Lettwin Analog Axon. IEEE Transactions On Biomedical Engineering, Vol.BME-30, pp. 139-140, ISSN 00189294

Silva, J.R.; Pan, H.; Wu, D.; Nekouzadeh, A.; Decker, K.F.; Cui, J.; Baker, N.A.; Sept, D. \& Rudy, Y. (2009). A multiscale model linking ion-channel molecular dynamics and electrostatics to the cardiac action potential. Proc Natl Acad Sci USA, Vol.106, pp. 11102-6, ISSN 1091-6490

Szabó, A.; Szentandrássy, N.; Birinyi, P.; Horváth, B.; Szabó, G.; Bányász, T.; Márton, I.; Nánási, P.P. \& Magyar, J. (2007). Effects of articaine on action potential characteristics and the underlying ion currents in canine ventricular myocytes. British Journal of Anaesthesia, Vol.99, pp. 726-733, ISSN 00070912

Szabó, A.; Szentandrássy, N.; Birinyi, P.; Horváth, B.; Szabó, G.; Bányász, T.; Márton, I.; Magyar, J. \& Nánási, P.P. (2008). Effects of ropivacaine on action potential configuration and ion currents in isolated canine ventricular cardiomyocytes. Anesthesiology, Vol.108, pp. 693-702, ISSN 00033022

Tanaka, H.; Komikado, C.; Shimada, H.; Takeda, K.; Namekata, I.; Kawanishi, T. \& Shigenobu K. (2004). The R(-)-enantiomer of efonidipine blocks T-type but not Ltype calcium current in guinea pig ventricular myocardium. Journal of Pharmacological Sciences, Vol.96, pp. 499-501 ISSN 13478613

Thiel, G. (1995). Dynamics of chloride and potassium currents during the action potential in Chara studied with action potential clamp. European Biophysics Journal, Vol.24, pp. 85-92, ISSN 01757571

Thomas, G.P.; Gerlach, U. \& Antzelevitch, C. (2003). HMR 1556, a potent and selective blocker of slowly activating delayed rectifier potassium current. Journal of Cardiovascular Pharmacology, Vol.41, pp. 140-147, ISSN: 01602446

Varro, A.; Balati, B.; Iost, N.; Takacs, J.; Virag, L.; Lathrop, D.A.; Csaba, L.; Talosi, L. \& Papp, J.G. (2000). The role of the delayed rectifier component IKs in dog ventricular muscle and Purkinje fibre repolarization. Journal of Physiology, Vol.523, pp. 67-81, ISSN 00223751

Wilders, R. (2006). Dynamic clamp: a powerful tool in cardiac electrophysiology. Journal of Physiology, Vol.576, pp. 349-359, ISSN 00223751

Xu, Y.; Tuteja, D.; Zhang, Z.; Xu, D.; Zhang, Y.; Rodriguez, J.; Nie, L.; Tuxson, H.R.; Young, J.N.; Glatter, K.A.; VÃ $i z q u e z$, A.E.; Yamoah, E.N. \& Chiamvimonvat, N. (2003). Molecular Identification and Functional Roles of a $\mathrm{Ca}^{2+}$-activated $\mathrm{K}^{+}$Channel in Human and Mouse Hearts. Journal of Biological Chemistry, Vol.278, pp. 49085-49094, ISSN 00219258

Yamada, M.; Ohta, K.; Niwa, A.; Tsujino, N.; Nakada, T. \& Hirose, M. (2008). Contribution of L-type $\mathrm{Ca}^{2+}$ channels to early afterdepolarizations induced by $\mathrm{I}_{\mathrm{Kr}}$ and $\mathrm{I}_{\mathrm{Ks}}$ channel suppression in guinea pig ventricular myocytes. Journal of Membrane Biology, Vol.222, pp. 151-166, ISSN 00222631 
Yuill, K.H.; Convery, M.K.; Dooley, P.C.; Doggrell, S.A. \& Hancox, J.C. (2000). Effects of BDF 9198 on action potentials and ionic currents from guinea-pig isolated ventricular myocytes. British Journal of Pharmacology, Vol.130, pp.1753-1766, ISSN 00071188. 


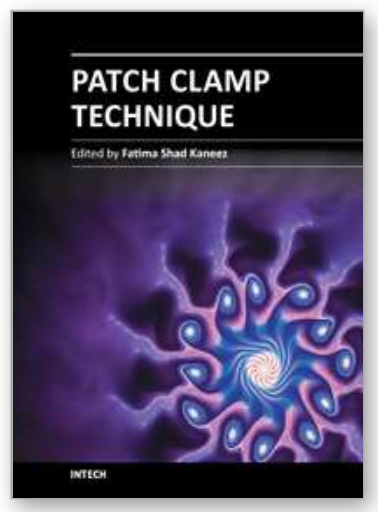

\author{
Patch Clamp Technique \\ Edited by Prof. Fatima Shad Kaneez
}

ISBN 978-953-51-0406-3

Hard cover, 356 pages

Publisher InTech

Published online 23, March, 2012

Published in print edition March, 2012

This book is a stimulating and interesting addition to the collected works on Patch clamp technique. Patch Clamping is an electrophysiological technique, which measures the electric current generated by a living cell, due to the movement of ions through the protein channels present in the cell membrane. The technique was developed by two German scientists, Erwin Neher and Bert Sakmann, who received the Nobel Prize in 1991 in Physiology for this innovative work. Patch clamp technique is used for measuring drug effect against a series of diseases and to find out the mechanism of diseases in animals and plants. It is also most useful in finding out the structure function activities of compounds and drugs, and most leading pharmaceutical companies used this technique for their drugs before bringing them for clinical trial. This book deals with the understanding of endogenous mechanisms of cells and their receptors as well as advantages of using this technique. It covers the basic principles and preparation types and also deals with the latest developments in the traditional patch clamp technique. Some chapters in this book take the technique to a next level of modulation and novel approach. This book will be of good value for students of physiology, neuroscience, cell biology and biophysics.

\title{
How to reference
}

In order to correctly reference this scholarly work, feel free to copy and paste the following:

Ye Chen-Izu, Leighton T. Izu, Peter P. Nanasi and Tamas Banyasz (2012). From Action Potential-Clamp to "Onion-Peeling" Technique - Recording of lonic Currents Under Physiological Conditions, Patch Clamp Technique, Prof. Fatima Shad Kaneez (Ed.), ISBN: 978-953-51-0406-3, InTech, Available from: http://www.intechopen.com/books/patch-clamp-technique/from-action-potential-voltage-clamp-to-the-onionpeeling-technique-recording-of-ion-currents-under-p

\section{INTECH}

open science | open minds

\author{
InTech Europe \\ University Campus STeP Ri \\ Slavka Krautzeka 83/A \\ 51000 Rijeka, Croatia \\ Phone: +385 (51) 770447 \\ Fax: +385 (51) 686166 \\ www.intechopen.com
}

\author{
InTech China \\ Unit 405, Office Block, Hotel Equatorial Shanghai \\ No.65, Yan An Road (West), Shanghai, 200040, China \\ 中国上海市延安西路65号上海国际贵都大饭店办公楼 405 单元 \\ Phone: +86-21-62489820 \\ Fax: +86-21-62489821
}


(C) 2012 The Author(s). Licensee IntechOpen. This is an open access article distributed under the terms of the Creative Commons Attribution 3.0 License, which permits unrestricted use, distribution, and reproduction in any medium, provided the original work is properly cited. 